\title{
The Caddo Oil- and Gas-Field, Louisiana.
}

BY WALTER E. HOPPER, ITHACA, N. Y.

(Wilkes-Barre Meeting, June, 1911.)

\section{Location and Extent.}

The Caddo oil-field, shown in Fig. 1, is located in Caddo parish, northwestern Louisiana. The known producing territory of oil is covered by townships $19 \mathrm{~N}, 20 \mathrm{~N}, 21 \mathrm{~N}, 22 \mathrm{~N}$, and ranges 15 and $16 \mathrm{~W}$., shown in Fig. 2. The center of the field may be taken as Oil City, 24 miles north of Shreveport, on the Kansas City Southern railway. Shreveport is the second largest city in the State, and is the connecting point of five railroad-lines. Drilling at the present time, however, is going on all over northern Louisiana, especially in Caddo and the neighboring parishes. During the winter of 1908-09 I spent four months in the Caddo field, under the direction of the Louisiana Geological Survey and the U. S. Geological Survey.

\section{History and Development.}

Natural gas escaping at the surface is found at numerous places in northwestern Lovisiana. At Shreveport, the plant of the Shreveport Ice \& Refrigerating $\mathrm{Co}$. has been lighted by natural gas for 20 years. The well was drilled for water, but was abandoned on account of the gas. A test well, put down in 1905 near the western limits of Shreveport, was driven to 1,650 $\mathrm{ft}$, and encountered indications of gas and oil at various depths, but did not succeed in finding enough to be profitable. Attention was first attracted to the Caddo field in 1895 by indications in water-wells from 40 to $60 \mathrm{ft}$. deep, in which the pressure of natural gas was noticeable. This indication of gas in a shallow well led to the drilling of the first well in the Caddo field, the old Savage Brothers \& Morricell, or the Caddo Lake Oil and Pipe Line No. 1. The rig for this well was erected in May, 1904, and drilling began in June, 1904. The well was bailed Mar. 23, 1905, with a small amount of oil. It was deepened July, 1905, and converted into a "gasser" Jan. 3, 1906. It was abandoned January, 1907.

In consequence of the finding of oil in the Savage well, drilling-operations were pushed with energy; and in April, 1905, 
four wells were drilling. Great trouble was experienced with gas blow-outs and several of the rige were shut down. Difficulty in obtaining wood for fuel during bad weather led to the abandoning, so far as oil was concerned, of the Producers' No. 1, which was then used to supply fuel-gas to the various drilling-rigs in the field.

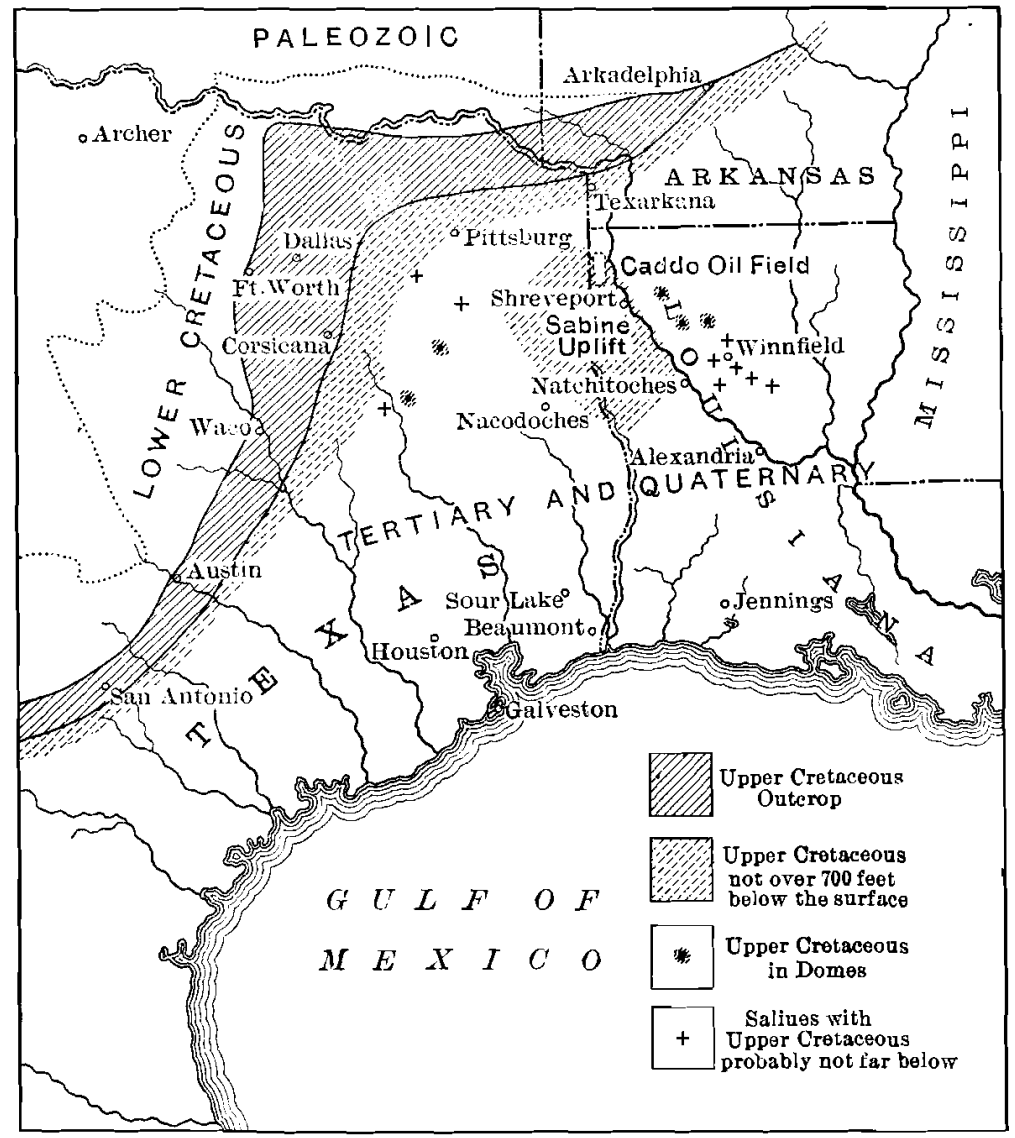

From Bulletin No. 8, Louisiana Geological Survey (1909).

Fig. 1.-Map Showing Iocation of Caddo Field in Reference to the SABINE UPLIFT.

On the afternoon of May 7, 1905, the Producers' No. 2 blew out. The roar of the gas was heard 14 miles away. On the afternoon of May 8 the ground near the hole caved in, taking with it a steam engine, a rotary drilling-rig, a 70 -ft. derrick, a hoisting-drum and steel cable, two Gardner pumps ( 10 by 6 by $10 \mathrm{in.}$ ), a tool-house (10 by $12 \mathrm{ft}$.) with full assortment of tools, 


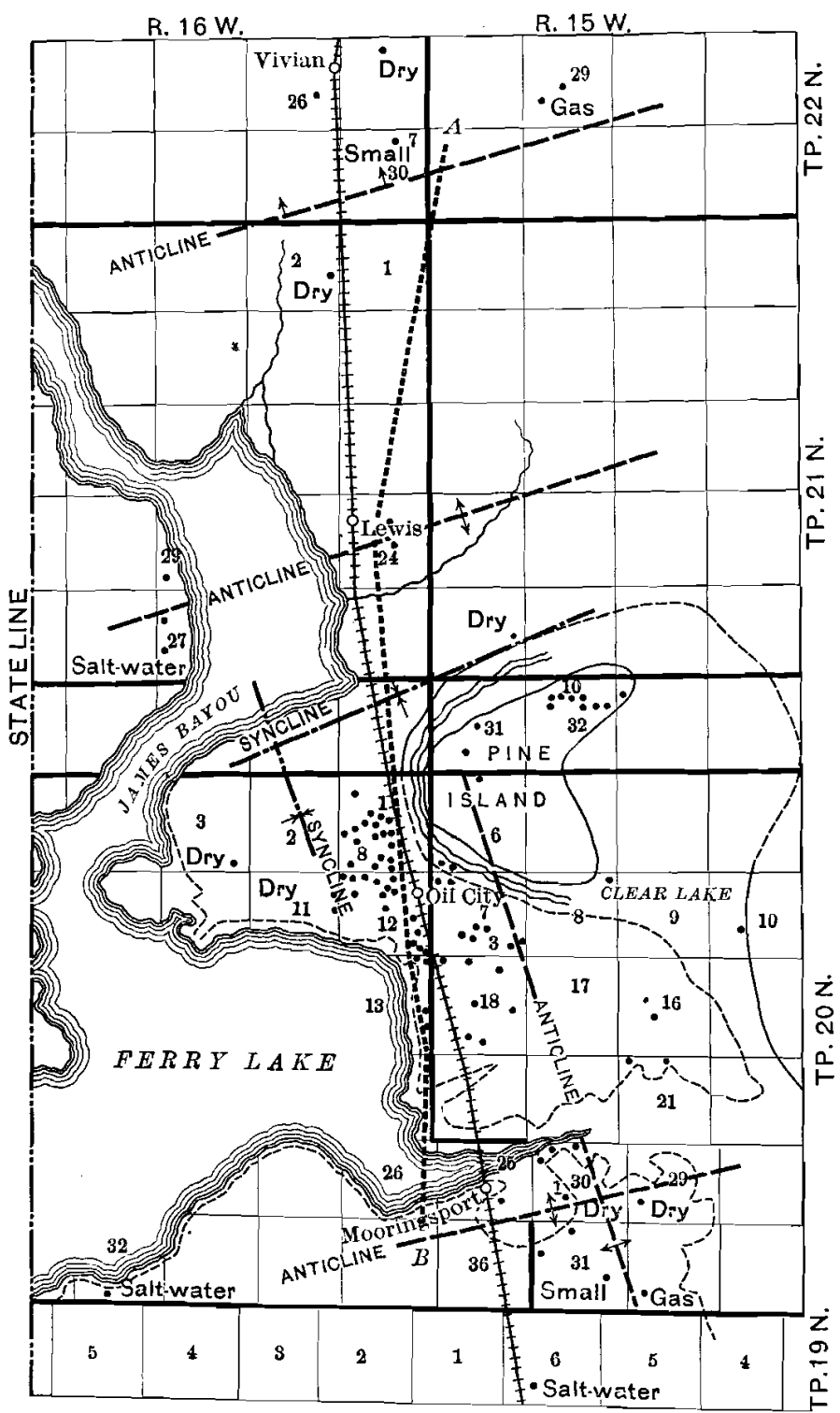

From Bulletin No. 8, Louisiana Geological Survey (1909).

Vivian region: Little oil, heavy ; much gas. Nacatoch horizon.

Lewis region: Little oil, heavy ; much gas. Nacatoch horizon.

Pine Island : Gas from the Nacatoch sands; heavy oil and gas from the Woodbine.

Oil City, Sections 1 and 12: Gas from the Nacatoch, Austin, and Woodbine; light oil from the A ustin, locally ; heavy oil from the Woodbine.

Oil City, south of, Sections 13 and 18: Gas in the Nacatoch and Woodbine; light and heavy oil in the Woodbine.

Mooringsport : Gas in the Nacatoch and Woodbine; light oil in the Woodbine, Sections 26, 25, and west $1-2$ of Section 30 .

James Bayou, west : Light oil in the Woodbine. Gusher territory.

Fig. 2.-Ovthine-Map of Caddo Field, Showing Structure and areas of Greatest Development. 
$150 \mathrm{ft}$. of 10 -in. casing, $400 \mathrm{ft}$. of 8-in. casing, $1,600 \mathrm{ft}$. of 6 -in. casing, and 1,600 ft. of 4-in. drill-pipe. A new location was immediately made $300 \mathrm{ft}$. NE. of the blow-out.

Drilling progressed slowly on account of the blow-outs. On June 18, Producers' No. 2 was lighted, the flames rising $100 \mathrm{ft}$. In July, 1905, one gas- and one oil-well were producing, eight were drilling, and seven new rigs were up. On Oct. 12, 1905, the contract was made to lay a 6 -in. gas-line 23 miles long, extending from the Caddo field to Shreveport, La. Four good "gassers". were then producing. In November, Producers' No. 3 blew out, and in December it caught fire, producing similar results to Producers' No. 2, which was on fire from June to November, when it choked up and died out. On Dec. 31, 1905, four "gassers" had been completed in the field; two wells had been completed for oil, but were not producing; three had been drilled and abandoned; three were drilling; and six locations had been made for new holes.

In February, 1906, the Citizens'. Oil and Pipe Line No. 1, in the south end of the Gilbert farm, blew out, throwing mud and water from the hole, $10 \mathrm{ft}$. wide on the outside of the casing, $100 \mathrm{ft}$. into the air. Pure gas in strong force came out of the 6-in. pipe. The well finally engulfed derrick, etc., and converted itself into the well-known oil-and-gas geyser. The well was set on fire and is still burning.

In the early part of 1906 the 6-in. gas-line from Caddo to Shreveport was completed. On May 24, natural gas from the Caddo field was made available for domestic consumption. The daily consumption in Shreveport was about 5,000,000 cubic feet.

During the latter part of the year several well's were drilled on Pine Island. In December, Producers' No. 1 on Pine Island was making 250 barrels. A site for a pump-station and tank-farm was acquired at Caddo City, and the laying of a 6 -in. pipe-line to Pine Island, about 2.5 miles, was begun. Loadingracks were erected on the Kansas City Southern railway. The first car-load of Pine Island crude oil was shipped from Caddo City to the refinery at Port Arthur on Dec. 13. Seven cars, or 1,510 barrels, had been shipped up to the close of December. The Caddo field produced 4,650 barrels in 1906. Several good "gassers" were also completed during the year.

Considerable drilling was done on Pine Island and north of Oil City during the early part of 1907. On May 23, a deep oil- 
well near the old Savage well was brought in, producing 100 barrels flowing. In June, 1907, there were ten big and one small "gassers" completed in the field. The ten wells varied in capacity from $8,000,000 \mathrm{cu}$. ft. to $25,000,000 \mathrm{cu}$. ft.; the aggregate daily capacity of the ten was put at $143,000,000$ cu. ft. On Sept. 14, 1907, a second gas-line from the Caddo field to Shreveport was completed. During the year 1907 eight producing wells, 11 "gassers," and four dry holes were completed, and nine holes were abandoned.

The year 1908 marked great activity in the Caddo field. Wells were put down north, south, and east of Oil City. In the spring an 8-in. gas-line was started from the Caddo field to Texarkana, Tex., a distance of 55 miles. In April, ten wells were flowing and producing oil. Several good "gassers" had been brought in at Dixie, La., 6 miles SE. of Oil City.

Mooringsport, 4 miles south of Oil City, was opened up with "gassers," and the Hostetter No. 1 in April. On May 11, 1908, the C. G. Dawes Trustee No. 1 blew out; the gas caught fire, and the well burned until Feb. 12, 1909.

A good oil-well was "drilled in" on Pine Island in May, 1908, and several were drilling. The field was considerably extended by the bringing in of a 50,000,000-cu. ft. "gasser" at Lewis, 4 miles north of Oil City, in July. Development was also started at Vivian, La:, 10 miles north of Oil City. In September, the best well yet completed in the field was brought in. This is the Producers' Lane No. 1, south of Oil City. It yielded from 2,500 to 3,000 barrels a day at the start, and produced 1,000 barrels daily for several months. In December, the Gulf Refining Hostetter No. 2 was brought in, producing 300 barrels, and calling everybody's attention to Mooringsport. On Dec. 15 there were 25 wells drilling. During the year 1908 Caddlo completed 43 producing oil-wells, eight "gassers," and seven dry holes; and two holes were abandoned.

In 1909 the output of the Caddo field was 985,226 barrels, as compared with 499,937 barrels the year before. In January the production averaged 2,177 barrels a day, and it gained at intervals until in November, when a deep well in new territory, 5 miles $\mathrm{NW}$. of the nearest producers, came in, flowing more than 3,000 barrels a day of 40 -gravity oil, the output went up to 3,711 barrels a day. During 1909 a 6 -in. pipe-line was laid from the Caddo field to a refinery on Grigsby's Island, south of Shreveport. 
During the year 1910 almost international attention was attracted to the Caddo field because of a number of large gushers of high-grade oil. During the year nearly twice as many wells were completed, with an initial flow almost 15 times as great as in 1909. The total production during 1910 reached $5,680,000$ barrels. For several months it was maintained at a rate of 20,000 barrels a day, but at the close of the year it declined to 14,000 barrels a day.

Three pipe-lines were laid from the field to the Gulf and to the Mississippi river. The Standard Oil Co. of Louisiana established a trunk-line connection with the field to the refiningplant at Baton Rouge. Late in the year the Gulf Pipe Line Co. installed a 6 -in. line from the west side of the field connecting with its 8 -in. Oklahoma trunk-line to Port Arthur. The Texas Co. completed an 8-in. line direct from Shreveport to its large station at Garrison, Tex. This company also established a storage-tank farm near Shreveport, where more than $1,000,000$ barrels was accumulated prior to the completion of the pipe-line. Late in 1910 the Standard Oil Co. took over the holdings of the J. C. Trees Oil Co., at a price believed to be about $\$ 4,500,000$. Prospecting is going on in every direction to discover more gusher territory of the light paraffin oil.

Final arrangements have been made for the natural-gas line from the Caddo field to St. Louis, and the work preliminary to construction is now under way. A 20-in. line is contemplated, and it is the plan to lay it as nearly on an air-line as possible, in order to save distance. There will be five compressor-stations, from 60 to 75 miles apart. The length of the line as indicated by the preliminary surveys will be 450 miles. The line will have a capacity of $80,000,000 \mathrm{cu}$. ft. per day.

The 16-in. line to be built by the Arkansas Natural Gas Có, surveys for which are now being made, to extend from the Caddo field to the larger cities of Arkansas, will have a maximum capacity of $30,000,000 \mathrm{cu}$. ft. daily. It is the general impression at present that the proposed line to New Orleans, a distance of 400 miles, will never take form. However, the gasline from the Caddo field to Houston, Tex., is almost a certainty. With all the various lines in operation that are proposed, and including the present consumption, it is estimated that the average quantity of Caddo gas consumed will be more than $125,000,000 \mathrm{cu}$. ft. per day. 
The production of the Caddo field is given in Table I.

TABLE I.-Production of the Caddo Field for the Years 1906, 1907, 1908, and 1909. ${ }^{a}$

1906.

December $14-250$ barrels. December $31--150$ barrels.

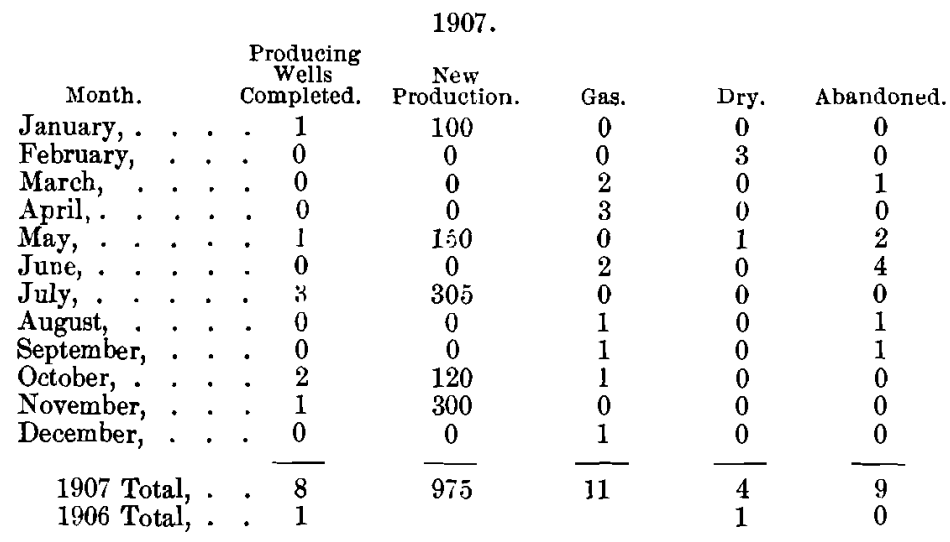

1908.

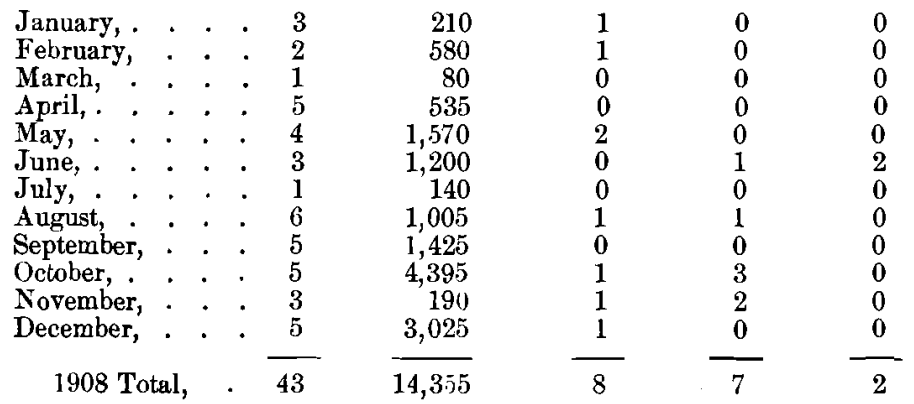

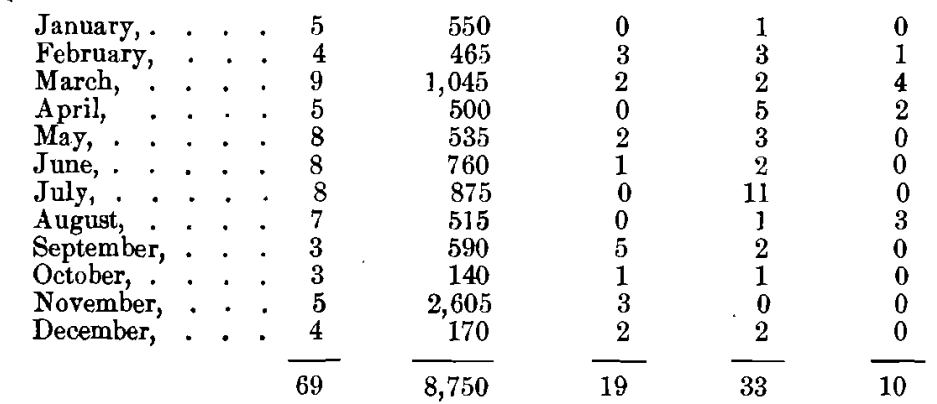

a Compiled from the Oil Investors' Journal. 


\section{GEOLOGY.}

In drilling for oil and gas in the Caddo field three systems of rocks are met with: the Quaternary, Tertiary, and Cretaceous. The Quaternary, made up of red clays and sands, is found on the surface. The Tertiary, composed of clays and sands with large boulders or concretions, underlies the Quaternary. The Cretaceous system, the oldest, is made up of more consolidated rocks, "gumbo," shale, chalk, etc.

The beds all dip towards the south, and the Cretaceous formations encountered in the Caddo field outcrop in Arkansas and Texas. Several structural peculiarities exist in Louisiana, the most noted being the Sabine uplift, due probably to a great crustal movement. Of this, Prof. G. D. Harris'says:

"It is the great Sabine uplift that affords the proper structure for the collection and retention of great quantities of oil and gas in northwest Lovisiana. The boundary of this uplift to the north, in the vicinity of Vivian, . . . . is clearly defined. Likewise to the south, from near Natchitoches to the Sabine. So, too, there is apparently a high dip to the east, in the Cretaceous beds along the course of the Red River. But to the west we have no sure proof that the Sabine uplift . . . may not be continuous with.... [an] area further west in Texas. In other words, the insular mass . . . . [the Sabine uplift] might perhaps be more properly shown in the form of a peninsula connecting with the main land toward the west. . . . . Caddo field is near the north angle of the Sabine uplift. Its oil and gas evidently cone up the north and east slopes of this uplift and then become entrapped beneath Upper Cretaceous and Eocene impervious beds. But the final distribution of these substances over the field is seemingly due to secondary strnctural features, slight anticlines and difference of porosity of the rocks in which the oil is contained."

Gas in large quantities seems to have, in the Caddo field, a more general distribution than oil.

There are apparently four horizons in the Caddo field at which oil and gas occur. These all belong to the Cretaceous system. Table II. presents a generalized section of the Caddo field, with a few selected logs.

1 Bulletin No. 8, Louisiana Geological Survey, p. 6 (1909). 
TabLe II.-Generalized Section of the Caddo Oil-Field.

\begin{tabular}{|c|c|c|c|c|c|}
\hline & & \multirow[b]{2}{*}{ 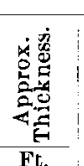 } & \multirow[b]{2}{*}{ 这 } \\
\hline System. & Series. & Stage. & Kind of Material. & & \\
\hline Quaternary. & & & $\begin{array}{r}\text { Red and gray sand, clay, } \\
\text { gravel............................. }\end{array}$ & $\begin{array}{l}\text { Ft. } \\
20\end{array}$ & 20 \\
\hline \multirow{2}{*}{ Tertiary. } & \multirow{2}{*}{ Eocene. } & Sabine. & 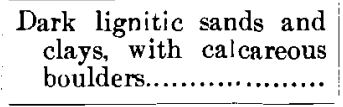 & 430 & 450 \\
\hline & & Midway. & $\begin{array}{l}\text { Dark clay, with occasion- } \\
\text { ally a limestone bed.... }\end{array}$ & 200 & 650 \\
\hline \multirow{8}{*}{$\begin{array}{l}\text { Cretaceous } \\
\text { (Upper.) }\end{array}$} & \multirow{2}{*}{ Montana. } & Arkadelphia. & Dark stiff clay.................. & 150 & 800 \\
\hline & & Nacatoch. & $\begin{array}{l}\text { "Slireveport" or "Caddo" } \\
\text { gas-sand ; contains some } \\
\text { hard layers................ }\end{array}$ & 130 & 930 \\
\hline & \multirow{5}{*}{ Colorado. } & Marlbrook. & $\begin{array}{l}\text { Blue marl with chalky } \\
\text { layers about } 1,150 \mathrm{ft} . \\
\text { (Saratoga chalk).......... }\end{array}$ & 350 & 1,980 \\
\hline & & \multirow[t]{2}{*}{ Austin. } & 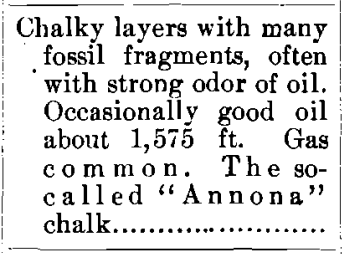 & 320 & 1,600 \\
\hline & & & $\begin{array}{l}\text { Chalk, clay, and sand, } \\
\text { with hard pyrite lavers. } \\
\text { The Brownstown beds...... }\end{array}$ & 200 & 1,800 \\
\hline & & \multirow[b]{2}{*}{ Eagle Ford. } & $\begin{array}{r}\text { Blossom sands. Gas at } \\
1,800 \mathrm{ft} \ldots \ldots \ldots \ldots \ldots \ldots \ldots\end{array}$ & 50 & 1,850 \\
\hline & & & $\begin{array}{l}\text { Blue tough clays with } \\
\text { hard limestone and } \\
\text { pyrite layers. The } \\
\text { "Eagle Ford clays."... }\end{array}$ & 350 & 2,200 \\
\hline & Dakota. & Woodbine. & $\begin{array}{l}\text { These sand-beds, reached } \\
\text { at depths ranging from } \\
2,140 \text { to } 2,300 \mathrm{ft} \text {., ac- } \\
\text { cording to local struc- } \\
\text { tural features, contain } \\
\text { the "deep" oil and gas } \\
\text { of the Ca d d o fields. } \\
\text { Salt water is common. } \\
\text { Thickness un kn ow n, } \\
\text { (100 ft.) }\end{array}$ & & \\
\hline
\end{tabular}


LOG OF FILER No. 1.

Record received from Mr. Plumb.

T

Clay...................

Sand................. $\tilde{5}$

Dark clay.......... 20

Rock................ 4

Clay ................. 11

Rock................ 3

Shale................ 57

Rock .............. 2

Shale............... 148

Rock................ 3

Shale................ 172

Rock................. 4

Gumbo.............. 121

Rock................ 5

Gumbo.............. 50

Shale, hard........ 20

Shale, soft-some gas.................

Shale and gumbo,

Rock.

Shale, lıard...........

Gumbo...............

Shale................

Gumbo...............

Gumbo...............

Shale................. 80

Lime, soft.......... 100

Lime, hard......... 140

Rock................ 10

Lime, soft.......... 80

Rock............... 10

Lime, soft ......... 25

Shale................. 115

Gumbo............. 80

Shale, hard......... 115

Rock.............. 5

Shale............... 110

Rock.................

Shale............... 5

Rock................ 10

Shale............... 75

Rock...............

Shale.............. 100

Good oil-sand....... 1

LOG OF C. G. O. HOSTETTER No. 1 GAS.

Record received from B. G. Dawes.

\begin{tabular}{|cc} 
Thick- & \\
ness. & Depth. \\
Ft. & Ft. \\
15 & 15 \\
11 & 26 \\
2 & 28 \\
24 & 52 \\
1 & 53 \\
27 & 80 \\
2 & 82 \\
43 & 125 \\
3 & 128 \\
32 & 160 \\
2 & 162 \\
58 & 220 \\
2 & 222 \\
58 & 280 \\
3 & 283 \\
27 & 310 \\
1 & 311 \\
64 & 375 \\
2 & 377 \\
45 & 422 \\
3 & 425 \\
65 & 490 \\
3 & 493 \\
144 & 637 \\
11 & 648 \\
& \\
9 & 657 \\
& \\
10 & 667 \\
91 & 758 \\
33 & 761 \\
16 & 777 \\
33 & 780 \\
& \\
& \\
3.5 & 783.5
\end{tabular}


LOG OF HEYWOOD No. 1, FEE.

Record received from $H$. H. Jones, Driller.

\begin{tabular}{|c|c|c|c|c|c|}
\hline & $\begin{array}{l}\text { Thick- } \\
\text { ness. }\end{array}$ & Depth & & $\begin{array}{l}\text { Thick- } \\
\text { ness. }\end{array}$ & Depth. \\
\hline Clay, variegated soft....... & $\begin{array}{l}\text { Ft. } \\
80\end{array}$ & $\begin{array}{l}\text { Ft. } \\
80\end{array}$ & Chark, white and soft..... & $\begin{array}{l}\text { Ft. } \\
11\end{array}$ & $\begin{array}{c}\text { Ft } \\
1,155\end{array}$ \\
\hline Bluish sand, water-bear- & & & Dark gumbo.................. & 53 & 1,208 \\
\hline ing.... & 10 & 90 & Dark shale........ & 21 & 1,229 \\
\hline Clay, dark, soft............ & 50 & 140 & Dark gumbo................. & 43 & 1,272 \\
\hline Hard dark rock .......... & 2 & 142 & Chalk, clayey to white, oil & & \\
\hline Dark soft clay................. & 8 & 150 & from 1,470 to $1,520 \mathrm{ft} .$. & 328 & 1,600 \\
\hline Hard dark rock............ & 3 & 153 & Black rocky gumbo....... & 100 & 1,700 \\
\hline Gumbo and shale, dark, & & & mbo......... & 80 & 1,780 \\
\hline ders.......... & 447 & 600 & Rock with some pyrite... & 5 & 1,785 \\
\hline $\begin{array}{l}\text { Gumbo and dark shales.. } \\
\text { Shale, dark, with persist- }\end{array}$ & 110 & 710 & $\begin{array}{l}\text { Coarse, variegated sand } \\
\text { with oil smell............ }\end{array}$ & 13 & 1,798 \\
\hline 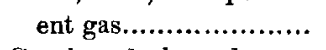 & 10 & 720 & Rock, in streaks and some & & \\
\hline Gumbo, dark and very & & & (n.............. & 62 & 1,860 \\
\hline 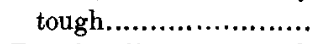 & 100 & 820 & Gumbo and shale........... & 112 & 1,972 \\
\hline Rough, lime-like rock & & & abo................ & 40 & 2,012 \\
\hline with gas.................... & 10 & 830 & Shale and dark gumbo... & 118 & 2,130 \\
\hline $\begin{array}{l}\text { Dry sand rock, with gas } \\
\text { and oil smell.............. }\end{array}$ & 34 & 864 & 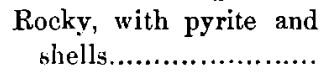 & 1 & 2,143 \\
\hline Rough lime rock............ & 5 & 869 & Red and dark shale....... & 37 & 2,180 \\
\hline Dry sand rock, with oil & & & Blue shale................... & 16 & 2,196 \\
\hline and gas.................... & 61 & 930 & Rock & 2 & 2,198 \\
\hline Hard rock.................... & 2 & 932 & Soft & 2 & 2,200 \\
\hline 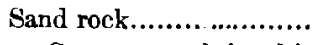 & 8 & 940 & rale.................. & 24 & 2,224 \\
\hline (Gas occurred in this & & & le..................... & 3 & 2,227 \\
\hline well from 820 to & & & ale................... & 5 & 2,232 \\
\hline $840 \mathrm{ft})$. & & & Oils & 4 & 2,236 \\
\hline Shales, with streaks of & & & Hard & 3 & 2,239 \\
\hline 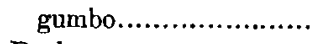 & 39 & 979 & & 3 & 2,242 \\
\hline 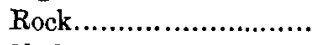 & 2 & 981 & Brittle rock................. & 10 & 2,252 \\
\hline $\begin{array}{l}\text { Shale and gumbo with } \\
\text { hard streaks................... }\end{array}$ & 16 & & Shale....................... & 5 & 2,257 \\
\hline
\end{tabular}

The Caddo oil is generally black, and ranges in specific gravity from $21.3^{\circ}$ to $41^{\circ}$ Baumé. The oil carries much water, but no sulphur.

An analysis of Caddo gas, made by Prof. C. F. Phillips, gave:

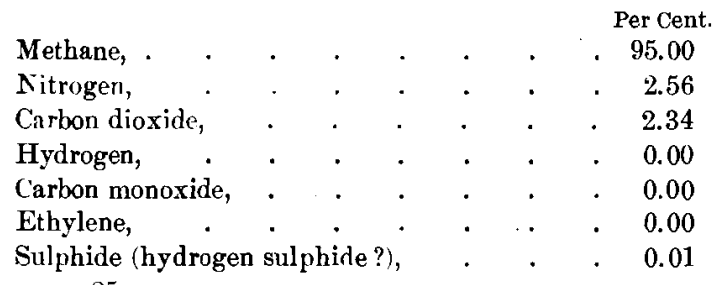

voL, XLII. -25 
IV. Topography.

The Caddo field lies in the Gulf Coastal Plain-an area of low and rounded relief rarely exceeding $500 \mathrm{ft}$. in elevation-and contains several small lakes, which are the most important recent topographic features of NW. Louisiana. Fig. 3 is a view of Ferry lake, near the center of the field, and Fig. 4 shows a small salt lake of the Producers' No. 2 blow-out. These lakes, due to the damming up of the Red river, have been formed since the fifteenth century. However, they are now returning to their former level as tributary streams.

Over most of the Caddo field are found low, circular, moundlike elevations, Fig. 5, from 20 to $100 \mathrm{ft}$. in diameter, with a maximum elevation of $6 \mathrm{ft}$. These mounds are very noticeable throughout the field, because of their persistence and wide distribution.

The condition of the ground and roads is far from good. The lakes and bayous almost completely surround with water the whole central portion of the field, and make the hauling of pipe and machinery exceedingly hard work. Salt-water ponds and swampy patches occur here and there; and, in general, the surface throughout the whole field presents swampy conditions. Fig. 6 shows the effect of a salt-water spray on surrounding trees and land.

\section{OWNERSHip OF LaNd.}

An operator may either own the land upon which he drills or lease it. Probably in the early development most drilling was done upon owned land. As the development increased, however, outside capital came in, to operate mostly on leascd land.

In 1907, two years after the opening of the field, land could be bought at from $\$ 25$ to $\$ 50$ per acre. At the time of the great boom in December, 1908 , the price jumped to $\$ 500$ and $\$ 1,000$. At present the cost per acre leased is from $\$ 50$ to $\$ 500$ per annum, with one-eighth of the product as the usual royalty.

In January, 1910, the assessor of Caddo parish announced that oil-lands would be assessed on the following basis: The owner of the fee to be assessed on the value of the land from a surface stand-point. The oil-rights to be assessed at oneeighth (or the royalty) to the owner of the fee, and seveneighths to the lessee. 


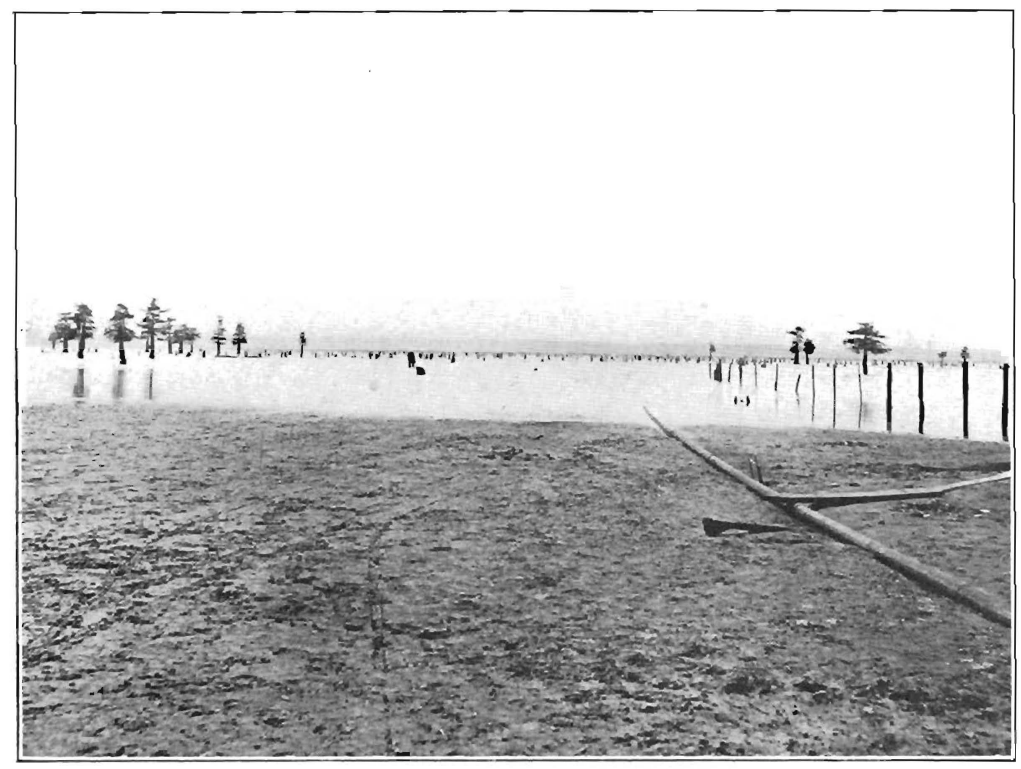

Fig. 3. - View Southinest over Ferry Lake near Center of Field.

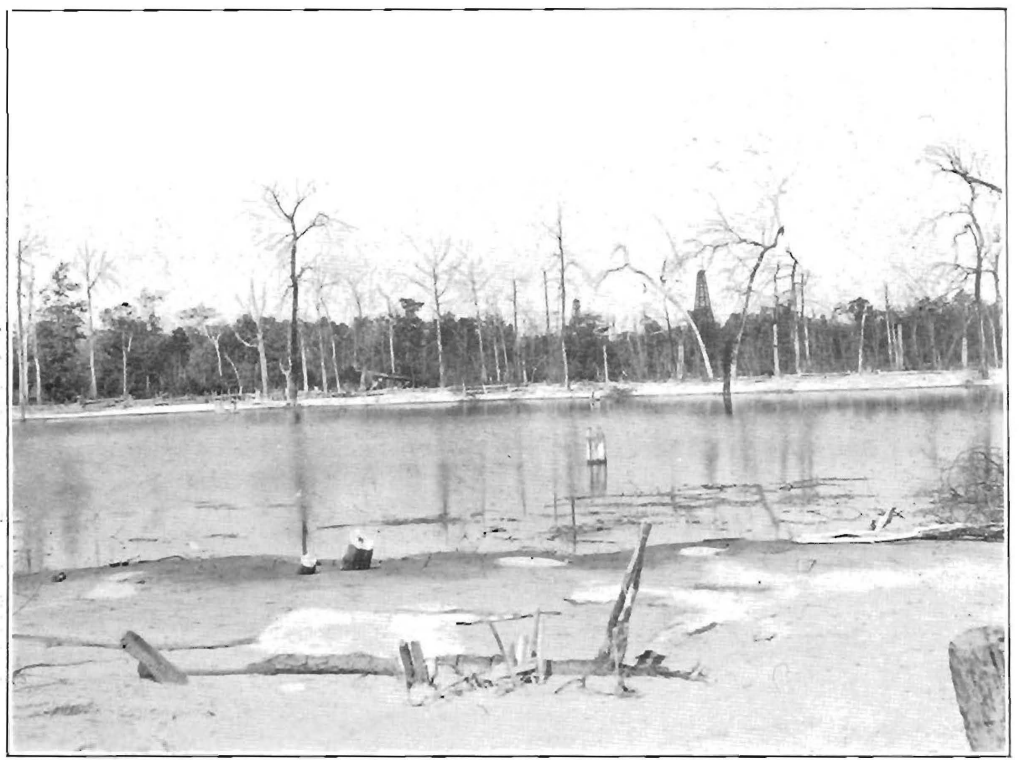

From Bulketin 1o. 429, L. S. Geological Surcey (1910).

Fig. 4.-Salt Lake Marking locatiox of the Producers' No. 2 Blow-OUt. 


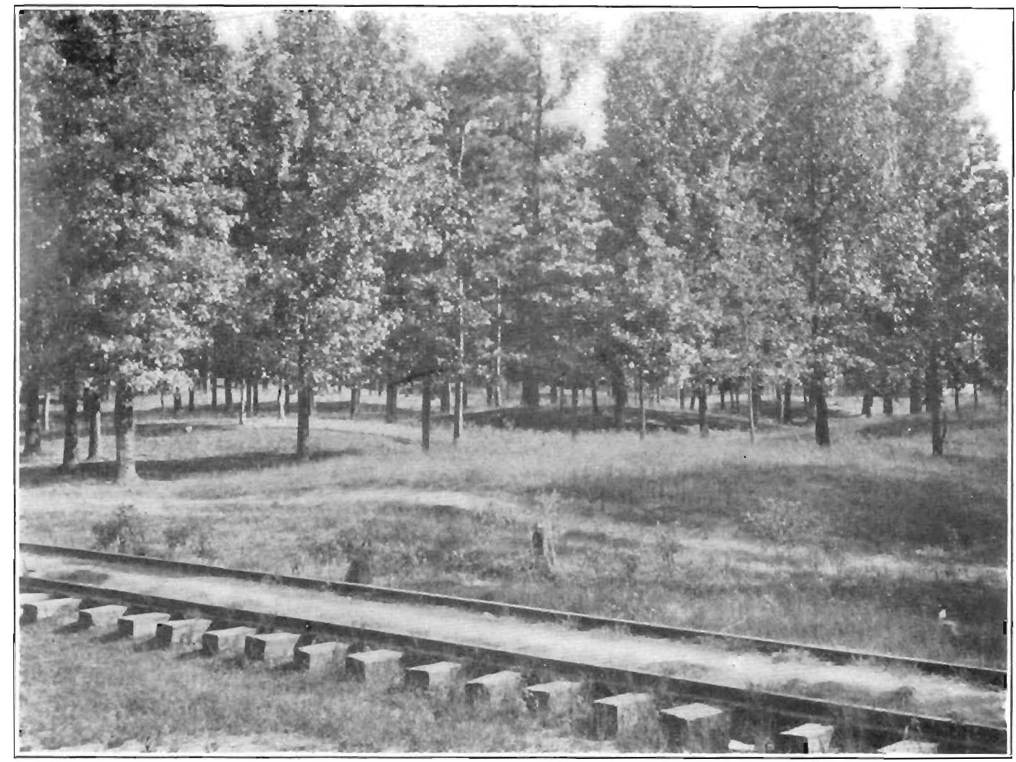

Fig. 5. - Gas-Mounds Northwest of Texarkana, Tex., a Noticeable Feature of the Topograpey of the Caddo Field.

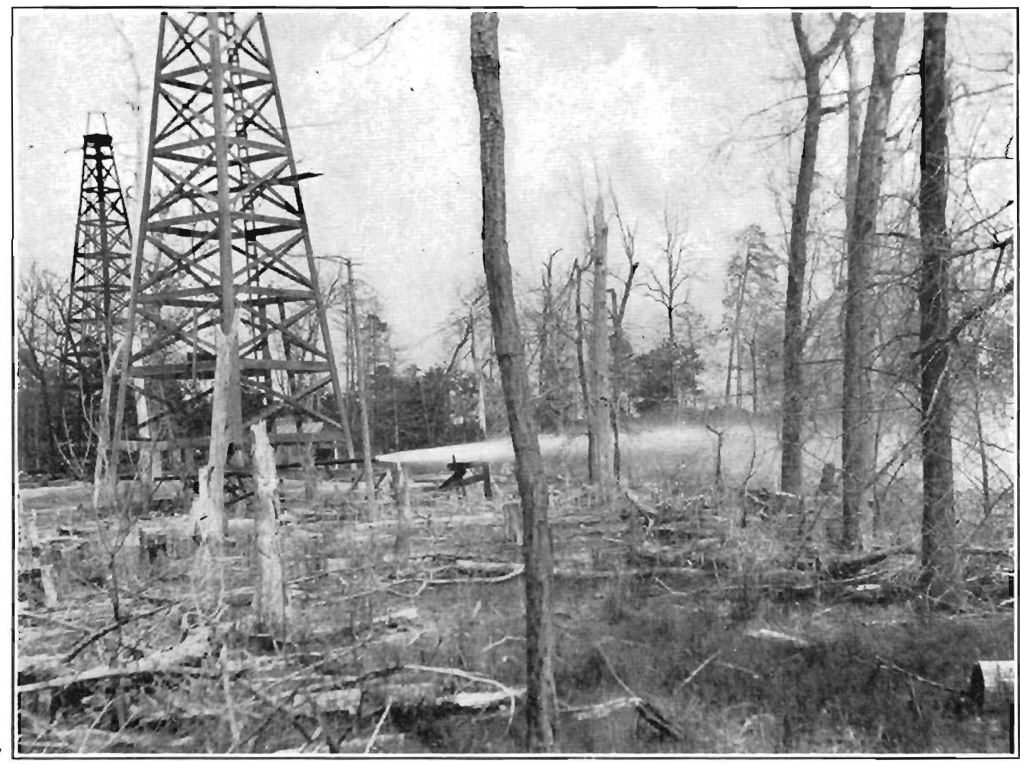

Fig. 6.-Producers' No. 1 Salt-Water Gusher, Showing the Effect of this Salt-Water Spray upon the Trees and the Surroundre IAAND. 


\section{Drilling-Operations.}

\section{Locating and Erecting Derrick.}

It is the common practice to place the derrick on one of the so-called gas-mounds, or as near as possible to a producing well. The average hire of a surveyor to locate a well is from $\$ 10$ to $\$ 25$.

The rotary derrick used can be easily framed and erected by any competent carpenter, although there are rig-builders here, as in every field. The building of a rig is by no means easy work; and every man who works up in the rig as it is erected generally receives $\$ 5$ per day. The derrick is usually $84 \mathrm{ft}$. high to the top of the crown-block, with a 22-ft. base. The cost of a rig or derrick, including lumber and labor, is about $\$ 250$.

\section{Machinery Equipment.}

Rigging up, one of the most expensive items to the operator or contractor, includes the purchasing and transporting of the rotary, engine, hoisting-machine, pumps, boiler, casing, and pipe. The cost of transportation of machinery and pipe from the railroad to the well varies from $\$ 150$ to $\$ 200$, according to distance.

There are several good rotaries now in use in the various oil-fields, each one possessing advantages for a particular field. I might mention the Parker rotary and the Oil-Well Supply rotary as two types used in the Caddo field. These rotaries vary in weight from 900 to $4,000 \mathrm{lb}$, and in size of pipe handled from 1.5 to $20 \mathrm{in}$. The price varies from $\$ 225$ to $\$ 1,600$.

Several makes of engines of $20,23,25$ and $28 \mathrm{~h}-\mathrm{p}$. are in use. The price of one of these engines complete varies from $\$ 320$ to $\$ 365$.

The hoisting-machines vary in weight from 1,990 to 2,800 lb., and in price trom $\$ 180$ to $\$ 250$.

Pumps of several styles are used in connection with the hydraulic rotary system. These are the Smith-Vaile, Knowles, Special Duplex, Gardner, and Parker rotary drilling-pumps. The price varies from $\$ 220$ to $\$ 510$.

The boiler, placed from 100 to $200 \mathrm{ft}$. away from the well, 
to insure against danger from an unexpected flow of gas or oil, is run by gas, generally supplied by a pipe-line from some gaswell in the field. The oil-country boilers, of locomotive type, are generally used. These are made of open-hearth flange steel, having a tensile strength of $60,000 \mathrm{lb}$. per square inch, and an elastic limit of $30,000 \mathrm{lb}$. They are tested at $160 \mathrm{lb}$. hydrostatic pressure and $125 \mathrm{lb}$. steam pressure per square inch.

The total cost for a complete rotary outtit, including tools and materials, f. o. b., is estimated at $\$ 2,825$, not including freight-charges. The weight of this outfit is about 30,000 pounds.

\section{Methods of Drilling.}

The hydraulic rotary method of drilling, used exclusively in the Caddo field, is a modification of the Fauvell system, invented in 1845, and used for some time in several of the European oil-fields. It is rapid and economical, when used in unconsolidated formations, such as clay, sand, or quicksand.

Several styles of rotary are used, but all work on the same principle. The principal features of the rotary outfit are the derrick, the rotary machine, the hoisting-gear, the engine, the boiler, and the pump. In addition are the numerous accessories and appliances for connecting the machinery; for attaching the pump to the boring-tube or casing; for hoisting and handling the tubes or casing; the bits or cutting-shoes; the pipe and casing.

The rotary method consists in rapidly turning a column of pipe, the lower end of which is armed with a steel shoe having a serrated edge or a bit for cutting. The drill-pipe is held by a chuck, and the descent of the pipe is controlled by the driller by means of a feeding-device. Water is kept under constant high pressure in the pipe and the cuttings are thus forced to the surface, passing up on the outside of the pipe with the water. This ascending current of water keeps the hole clean and allows the drill to turn freely. It is essential that the flow of water should be continuous, and a drilling-outfit is always supplied with two force-pumps in order to prevent any stoppage of the flow. If the drill has passed through a pervious stratum, such as a bed of loose sand, the ascending water is liable to pass into that stratum instead of returning to the 
surface. This quickly results in the clogging of the hole; and in order to prevent it the water which is pumped in is mixed with a large amount of fine clay. By this means the outlets through porous beds are sealed up, the unconsolidated material forming the walls of the hole is prevented from caving, and the water returns unimpeded to the surface. When drilling through quicksand or similar formations, a back-pressure valve is inserted in the coupling above the tirst joint of pipe, to prevent water and sand from rushing back into the pipe when the service is disconnected. This also assists materially in sustaining the wall of the well and permitting the pipe to turn. When the pipe has reached the desired depth, the valve, which is constructed of brittle material, is punched out, and the pieces either removed or forced down outside of the pipe.

When the formation is not of sufficient hardness to form a core, but washes out as the pipe advances, the rotary steel shoe with a serrated edge is used. In cases where the formation is composed of clay of sufficient density to retain the wall of the well in place, a smaller pipe is used, armed with a perforated bit, through which the water is forced from above, and when the depth is reached where it may be desirable to insert the casing, the drill-pipe is removed and the casing is inserted in the hole thus prepared for it.

Two forms of bit are generally used, the fish-tail and the core-barrel. The fish-tail bit requires considerable care both in making and in dressing. It cuts through comparatively hard formations, and must be so shaped that, as the points advance and outline the hole, the center portion crumbles the core which tends to form, and the small holes must direct the jets of water in such a way that the bit as well as the hole is kept clean. The core-barrel bit is used when a stratum is encountered which is too hard to yicld readily to the fish-tail bit. This core-barrel consists of a piece of steel pipe, about $8 \mathrm{ft}$. long, swaged at the upper end to connect to the drill-pipe. The lower end is left smooth, and two or three holes are drilled a short distance above, to permit the water to pass out and return to the surface. Chilled iron or steel particles averaging about the size of bird-shot are fed down the inside of the pipe in small quantities and find their way to the bottom of the hole, where they are rolled between the bottom of the core and the 
rock, rapidly crushing the latter. As the cuttings rise above the heavier shot, they are caught in the current of water and carried to the surface. The core is removed by means of an extractor consisting of a piece of pipe of the same size as the core-barrel and provided with short inwardly-projecting steel springs which engage the core and carry it up when the pipe is removed. It is necessary to exercise care, in pumping water, to admit only enough to remove the cuttings and not wash out the shot.

In starting a well arrangements are generally made first for a 12-in. casing; and in boring for this size the drill-pipe is generally made of 6 -in. casing with a 13.5-in bit. This size of bit is used to allow the collars at the joints of the 12-in, casing to slide past without damaging the wall of the well. The length of 12-in. casing used varies from 500 to $800 \mathrm{ft}$., depending largely upon the nature of the ground and the skill of the driller. The hole is generally left open until the whole depth calculated for one string of casing has been drilled. This generally extends until a hard stratum is met, upon which the casing to this depth may stand.

Following the 12-in. casing, the hole is next drilled for an 8-in. or 9-in. casing. In either case a 10.5-in. bit is used. After the 9-in., a 6-in. casing is used; then a 4-in., and then finally a 2 -in. casing.

The drilling depends largely upon the driller, who controls the engine and the drilling-pipe. It is necessary to keep the hole clean, and the pumps are generally kept going even though not drilling. Very often the well becomes clogged and it is necessary to pull out the whole string of pipe in the hole. The bits also require dressing, which necessitates the withdrawal of the pipe. The pipe is generally drawn out in sections of three lengths, or about $60 \mathrm{ft}$. It is stood up on the derrick-floor until put in the hole again. The cuttings as they are washed out by the water under the rotary are examined every 20 to $50 \mathrm{ft}$, and a $\log$ or record of the well is kept by the driller.

When the oil-bearing formation is reached, the oil will be noticeable on the water as it passes into the slush-pit. When, in the driller's judgment, the drill has penetrated the oil-bearing formation to a sufficient depth to assure a good flow, the pipe is removed and the well is bailed. A strainer is generally 
set at the bottom of the hole before bailing. The 10- or 20-ft. bailer, generally used, is lowered to the bottom of the well, the dart-valve opened, and the water allowed to fill the bailer. It is then pulled up and the water dumped into the slush-pit. Before the well is entirely bailed a gate-valve is fitted to the casing, in such a way as to permit a rapid closing of the well if desired. As soon as enough water has been removed to reduce the pressure the oil rises and the well flows. The well is allowed to clean itself of all loose pieces of rock or gravel, when the valve is closed and the well shut in. The well is then connected by a pipe-line to storage-tanks, a cooking-tank, or the loading-rack. In drilling for gas great caution must be taken to prevent a blow-out. A special quick-closing gatevalve set in cement is now used.

Five men usually make up the crew of a well: the driller, derrick-man, boiler-man, and two helpers. The driller is in complete charge of the drilling of the well. The daily wage of the driller varies from $\$ 5$ to $\$ 6$. Night-drillers sometimes receive more than this. The derrick-man receives from $\$ 3$ to $\$ 5$ per day or night, and the helpers $\$ 3$ per day or night.

The average length of time required to drill a deep well, that is, 2,200 ft., in the Caddo tield is from 120 to 180 days. Very often a night-and a day-crew are employed aud the length of time is then reduced to from 60 to 90 days. The length of time required to drill a shallow well $(800 \mathrm{ft}$.) is 30 days, or about 18 days, drilling day and night.

Besides the hydraulic rotary system of drilling, the standard or cable-tools method has been used in the Caddo field, but without satisfactory success. J. C. McCue, superintendent of the Producers' Oil Co., writes: "You will please note that I answer by saying-_ Impossible to drill with cable tools.' We find that the formation is such that cable tools caunot be used."

The drilling of a well by this cable-tools method is done with a steel drill, measuring with its fittings $30 \mathrm{ft}$. in length, and weighing from 1 to 1.5 tons. This drill is continually lifted and dropped in the hole, the force of its impact breaking the rock. At intervals the débris is removed by a sand-pump-a tube with a valve at the bottom, which is lowered into the hole and drawn out, bringing the cuttings with it.

Four men are required on a standard rig--the driller, boiler- 
man, and two helpers. The wages of the driller are $\$ 180$ per month and of the helpers $\$ 4$ per day. The total cost to build a standard rig is about $\$ 750$, while the estimated cost of tools, not including machinery, is about $\$ 2,000$.

Very often the oil in a well is not sufficient for the well to flow, in which case a pump is put on the well. In the Caddo field few gushers are brought in; hence a large majority of the wells are pumped. A standard rig, built for the pumping, costs about $\$ 600$. Recently two air-compressors have been installed. Wells producing large quantities of water with the oil are best blown by conpressed air; incleed, it is the only way to handle them. Fig. 7 is a view of a well on Pine Island blown by an air-compressor.

Frequently, when the oil-bearing formation is reached, the oil either does not flow at all or flows only in small quantities. Instead of putting the well on the pump, it is sometimes "shot." By exploding a charge of nitro-glycerine at the bottom of the hole, the surrounding rock is broken up and the flow of oil stimulated. The shooter lowers the glycerine into the well in cylindrical tin shells. The well is then filled for a couple of hundred feet with water to "tamp" the charge. The shooter lights the fuse of a "jack squib," a long slender shell filled with a small charge of glycerine, a fulminating-cap, and a slow-burning fuse, and starts the squib down the well. I have record of only one well having been shot in the Caddo field, and this with no success. The explosive in this case cost $\$ 275$.

\section{Treatment of Product.}

\section{Cooking.}

Several of the wells in the Caddo field produce oil containing much mud and water. Since the maximum percentage of dirt allowable is 3 per cent., it is necessary to "cook" the oil to free it from such impurities. The stationary "cooker," commonly used, has a capacity of 1,000 barrels in $24 \mathrm{hr}$. The cooking-tanks are built as follow' A small gas-mound is selected, in which a hole is excavated as large as the tank is to be, but not deeper than the level of the surface surroninding the mound, Fig. 8. The tank is then built inside the pit. The walls are double, of 2 in. plank, with a space between, which is 


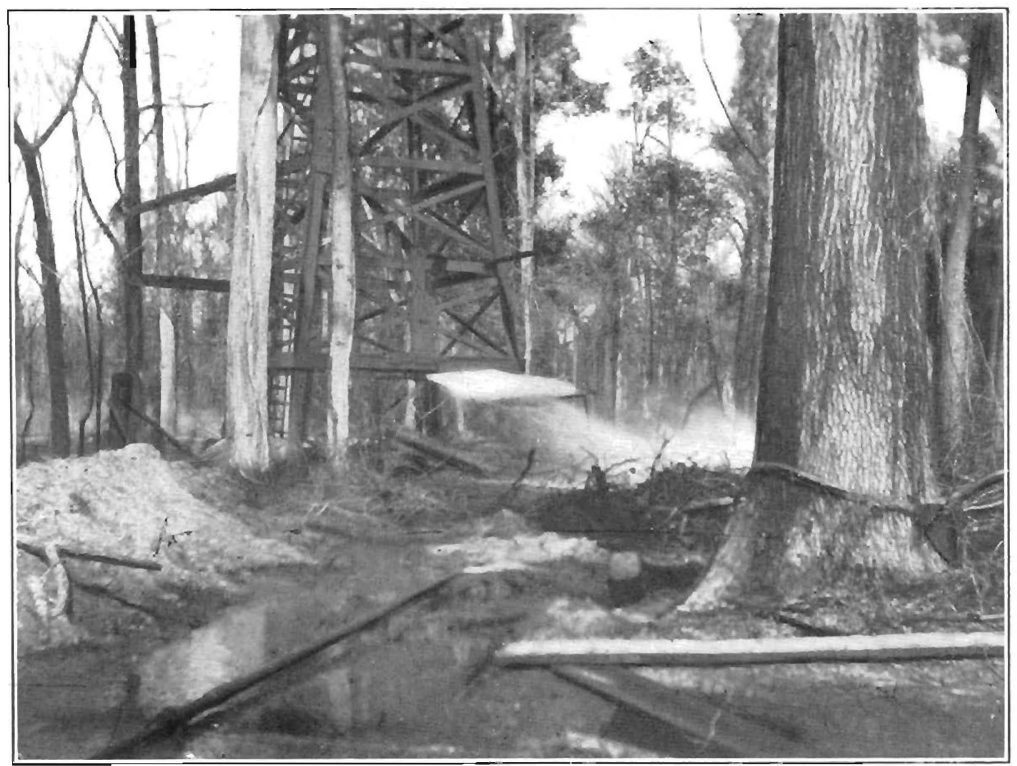

Fig. 7.-Well on Pine Island Berng Blown by an Air-Conpressor.

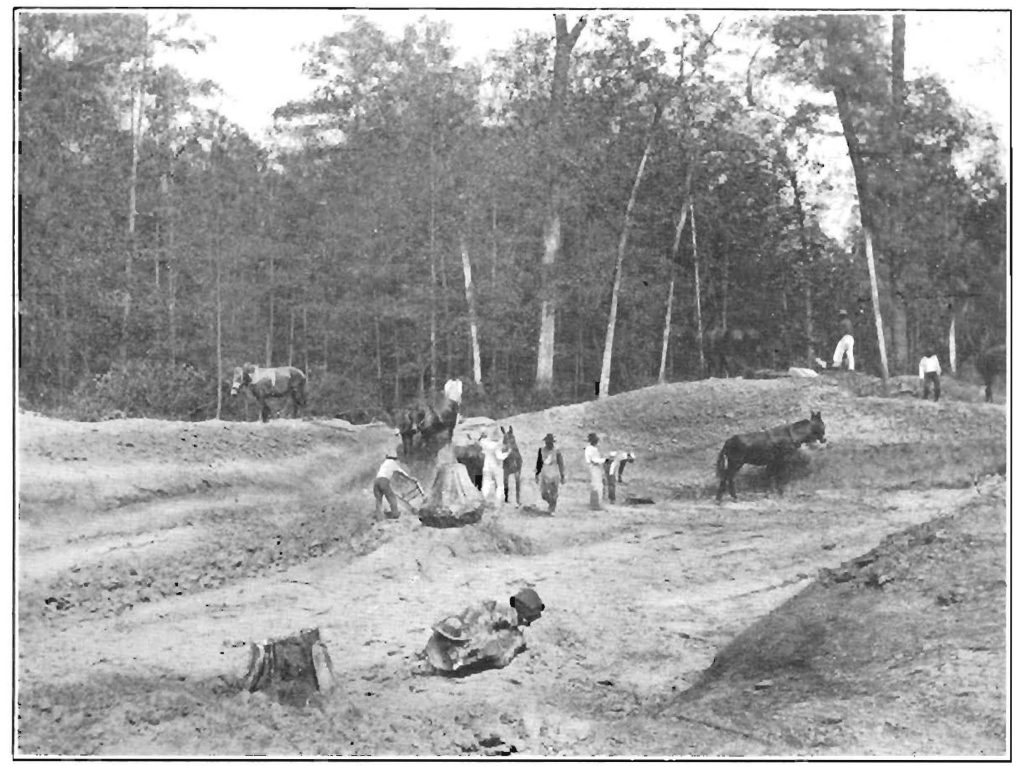

Fig. 8. Excapating a Gas-niound for the Bujlding uf a CookingTANK. 


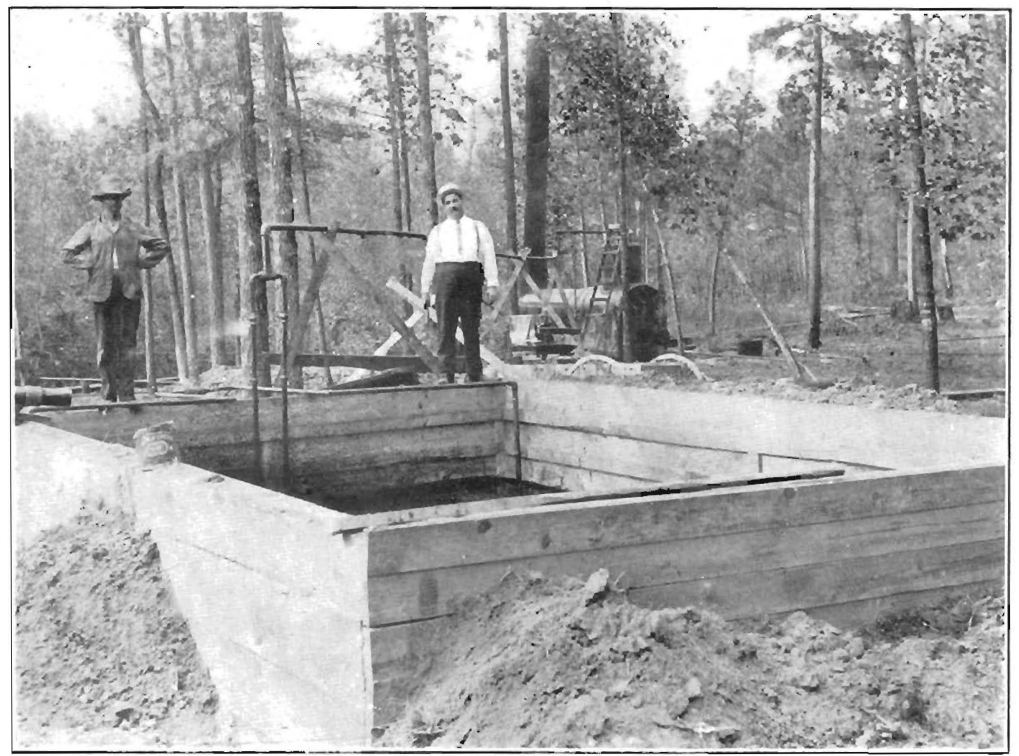

From Bulletin No. 8, Louisiana Geological Survey (1909).

Fig. 9.-Cooking-Tayk for the Bolling of Ory Carrirg Salt-Water AND MLD.

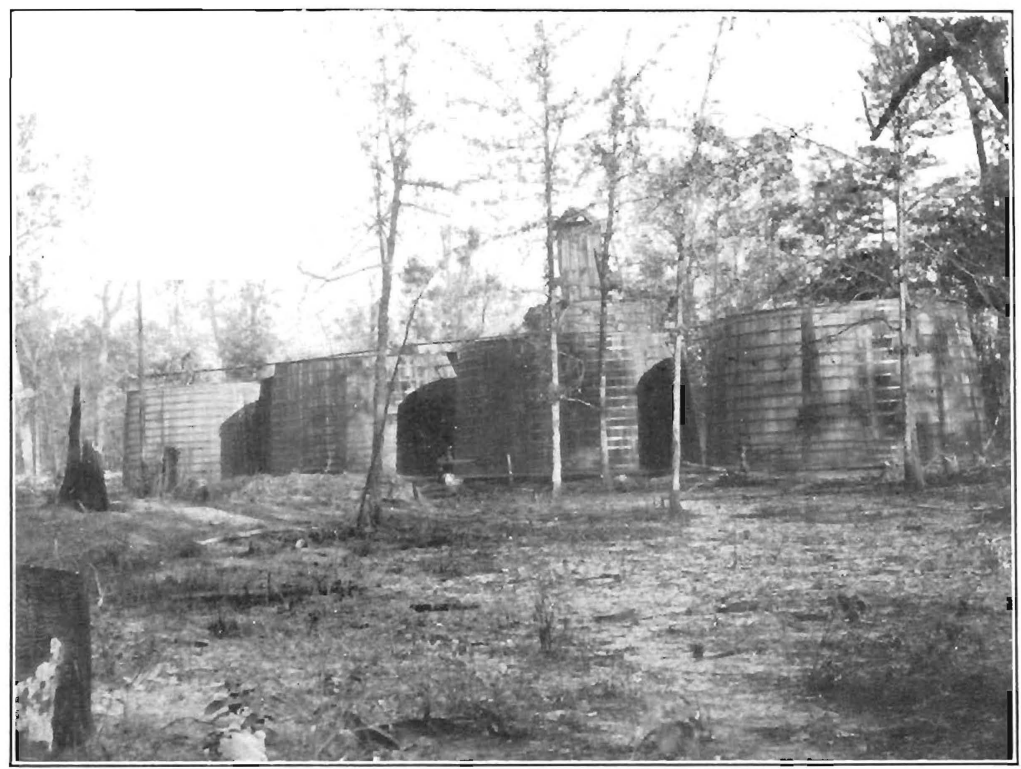

Fig. 10.-Wooden Storage-Tanks, 1,200 Barrils Capacity, of thf Filer Oil Co. 
afterwards filled with sand and the cracks calked with oakum, Fig. 9. Coils of 1.25-in. steam-pipe are then put in and the cooker is ready. In building the tank it is necessary to provide an opening for drawing off the water and letting the oil out after it has been steamed, and still another to let out the mud when the pit is cleaned. In cleaning these pits a bose attached to a water-pump is used, and water is pumped into the pit with great force.

The temperature of the oil is just as hot as the steam can make it. The length of time of cooking varies according to the quality of the oil. If it contains 80 per cent. of mud and water it will require $8 \mathrm{hr}$. of steaming for 400 barrels of the oil.

\section{Storage.}

Every producing well has one or more storage-tanks for its product. The tanks are of wood, bound with iron hoops, and have a truncated conical shape, and a capacity of 100,250 , $600,800,1,000$, or 1,200 barrels. In the Caddo field the 600 - and 1,200-barrel sizes are generally used, Fig. 10. After the wellconnections are made and the pipe-line is connected to the tank, a square wooden house is built over the tank to protect it from the weather. The cost of a 600 -barrel wooden tank is about $\$ 300$, and that of a 1,200 -barrel one about $\$ 500$.

A company operating a number of producing wells in this field generally builds a large steel storage-tank with a capacity of from 30,000 to 50,000 barrels, at a cost of about $\$ 0.28$ per barrel of capacity, or $\$ 9,800$ for a 35,000 -barrel tank.

Companies operating more than one well employ a gauger, whose duty it is each day to sample and measure the depth of the oil in the storage-tanks. The wages of a gauger are $\$ 3.50$ per day.

\section{Transportation.}

The oil, after it has been cooked, or direct from the well, is piped to the loading-rack. In the Caddo field there are at present five loading-racks, which vary in capacity from 20 to 60 cars. From there the oil goes direct to the refinery or to the buyer over the Kansas City Southern railway. 
Car-shipments of oil from the Caddo field (barrels of 42 gal.):

\begin{tabular}{|c|c|c|c|c|c|}
\hline $\begin{array}{r}\text { Year } 1909 . \\
\text { January, . }\end{array}$ & $\begin{array}{r}\text { Oil City. } \\
.51,400\end{array}$ & $\begin{array}{c}\text { Mooringsport. } \\
6,359\end{array}$ & $\begin{array}{l}\text { Vivian. } \\
\ldots \ldots \ldots\end{array}$ & $\begin{array}{l}\text { Lewis. } \\
\ldots \ldots \ldots\end{array}$ & $\begin{array}{r}\text { Total. } \\
57,759\end{array}$ \\
\hline February, . & . 81,690 & 6,699 & $\ldots \ldots$ & ........ & 88,389 \\
\hline March, & . 55,925 & 10,145 & $\ldots \ldots$ & ....... & 66,070 \\
\hline April, . . & . 56,622 & 3,658 & $\ldots \ldots$ & 2,935 & 63,215 \\
\hline May, . & 7,979 & .......... & $\ldots \ldots$ & 2,086 & 40,065 \\
\hline June, . . & . $\quad 51,529$ & 18,430 & 4,447 & 3,115 & 77,521 \\
\hline July, & . 48,756 & 35,593 & 4,025 & 2,053 & $90,4 \cdot 27$ \\
\hline August, . & . $\quad 38,162$ & 23,022 & 1,646 & 2,380 & 65,210 \\
\hline September, & . 37,414 & 26,633 & ........ & 2,245 & 63,292 \\
\hline October, . & . 49,313 & 41,922 & $\ldots \ldots$ & 1,076 & 92,311 \\
\hline November, & . 49,852 & 15,737 & $\ldots \ldots \ldots$ & ....... & 65,589 \\
\hline December, & . $\quad 49,599$ & 11,380 & $\ldots \ldots$ & ....... & 60,979 \\
\hline Totals, & 608,241 & 196,578 & 10,118 & 15,890 & 830,827 \\
\hline
\end{tabular}

Runs of crude oil from the Caddo field:

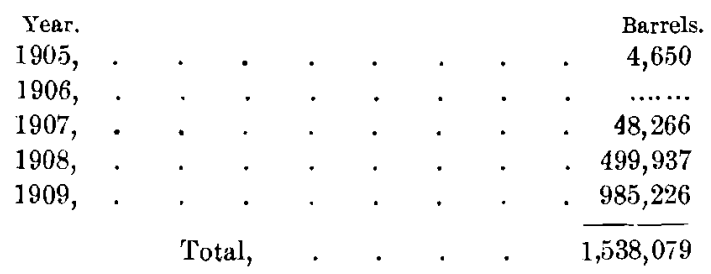

The gas-wells are connected with the main line, or the product is used to supply the drilling wells in the field.

\section{Consumption of Oil and Gas.}

A large part of the crude oil which does not go to the refinery is used by the Texas and Louisiana railroads, consuming daily about 16,500 barrels of fuel-oil. Table III. gives the approximate quantity of oil used by the various railroads in 1909. 
TaBle III._Consumption of Crude Oil by Railroads in 1909.a

Name.

Southern Pacific R. R.,

Gulf, Colorado \& Sante Fe R. R., .

Kansas City Southern R. R.

San Antonio \& Aransas Pass R. R.

International \& Great Northern R. R.

St. Louis, Brownsville \& Mexico R R.,

Trinity \& Brazos Valley R. R.,

Galveston, Houston \& Henderson R. R.

Gulf \& Interstate R. R.,

Texas \& Pacific R. R,

Houston Belt \& Terminal R. R.,

Galveston Wharf \& Terminal R. R.

$$
\begin{array}{r}
\text { Barrels. } \\
2,195,000 \\
1,793,288 \\
665,000 \\
480,000 \\
360,000 \\
145,000 \\
145,000 \\
60,000 \\
48,000 \\
48,000 \\
48,000 \\
36,000 \\
\hline 6,023,288 \\
16,502
\end{array}
$$

a From the Oil Investors' Journal, vol. viii., No. 18, p. 85 (Feb. 20, 1910).

All but a small portion of the oil consumed by the railroads named in Table III. is burned on the locomotives. A small quantity is used by several of the lines at their shops and for pumping water.

Table III. shows the total number of barrels of oil used by the Kansas City Southern railway. The amount of crude oil supplied to this railway from the Caddo field is as follows: From Oil City, 257,461; from Vivian, La., 18,412; and from Lewis, La., 1,087, making a total of 276,960 barrels.

Caddo gas is used in Shreveport, La., 20 miles south of the field. The price charged is $\$ 0.30$ per $1,000 \mathrm{cu}$. ft. for domestic purposes and about $\$ 0.15$ for manufacturing uses.

A flat rate of $\$ 0.50$ per month for heating and $\$ 0.10$ per month for lighting is maintained in the field.

Caddo gas is also used in Texarkana, Ark.; Dixie and Belcher, La. With the completion of the new lines, Caddo gas will be carried to St. Louis, Mo., to Houston, Tex., and possibly to New Orleans, La.

During the early part of 1909 , the estimated daily waste of gas in the field by the two burning gas-wells, the Caddo Gas and Oil Gilbert No. 1, and the C. G. Dawes Trustee No. 1, was about $75,000,000$ cubic feet. 


\section{Cost.}

The general impression is that it costs from $\$ 10,000$ to $\$ 12,000$ to drill a deep well in Caddo field.

C. W. Brown, of Brown Brothers, well-contractors, has stated the cost of drilling an oil-well to the depth of $2,200 \mathrm{ft}$. at approximately $\$ 10,000$, and that of a gas well $1,000 \mathrm{ft}$. deep at about $\$ 4,000$.

The following data show the average cost of drilling a deep well.

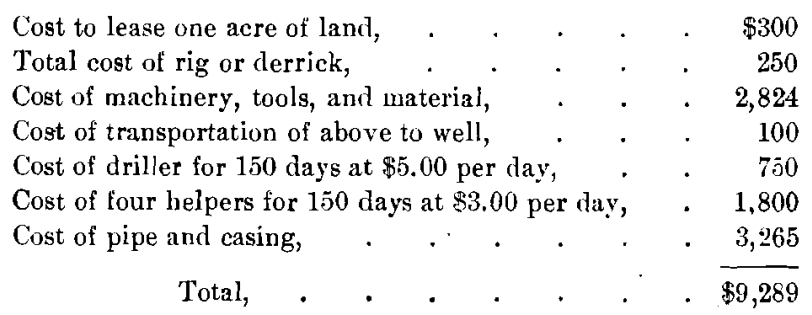

With oil worth $\$ 0.44$ a barrel, it would be necessary to have a production of 21,111 barrels in order to pay expenses. When one considers that a good well in the Caddo field means 200 barrels per day, some idea of the returns an operator receives can be obtained.

The review of the Caddo field for 1909 shows 69 oil-wells completed, with an initial output of 8,750 , and an average of 127 barrels; 19 "gassers" completed; 33 dry holes drilled; and 10 wells abandoned.

The 69 oil-wells represent a total expenditure of about $\$ 690,000$. The 19 gas-wells represent about $\$ 76,000$. Assuming 25 of the dry holes to have been deep holes, we have $\$ 250,000$ spent on these holes; and assuming 8 to have been "gassers," we have $\$ 32,000$ for these. The total expenditures for oil-wells would thus be $\$ 940,000$ and for gas-wells $\$ 108,000$. No doubt the same machinery was used to drill several wells; but still the foregoing figures furnish an idea of the amount of money spent in the field during the year 1909. Besides the drilling, there are the pipe-lines, storage-tanks, pumps, loadingracks, and cooking for the oil; also the pipe-lines for the gas.

The cost of lap-welded pipe is, at the low est average, about 3 cents per pound, including the joint. The cost of hauling, lay- 
ing, and painting, per foot, as given by the Oil Investors' Journal, is:

\begin{tabular}{|c|c|c|c|c|c|}
\hline $\begin{array}{l}\text { Size. } \\
\text { 2-in. }\end{array}$ & $\begin{array}{l}\text { Cost. } \\
\$ 0.24\end{array}$ & $\begin{array}{c}\text { Hauling. } \\
\$ 0.01\end{array}$ & $\begin{array}{l}\text { Laying. } \\
\$ 0.03\end{array}$ & $\begin{array}{c}\text { Painting. } \\
\$ 0.01\end{array}$ & $\begin{array}{l}\text { Total. } \\
\$ 0.29\end{array}$ \\
\hline 4-in. & 0.41 & 0.02 & 0.03 & 0.01 & 0.47 \\
\hline 6-in. & 0.65 & 0.02 & 0.04 & 0.02 & 0.73 \\
\hline 8-in. & 1.05 & 0.02 & 0.04 & 0.03 & 1.13 \\
\hline 10-in. & 1.30 & 0.03 & 0.05 & 0.03 & 1.41 \\
\hline 12-in. & 1.70 & 0.04 & $0.0 \overline{5}$ & 0.03 & 1.8 \\
\hline 16-in. & 2.80 & 0.05 & 0.06 & 0.04 & 2. \\
\hline 18-in. & 4.00 & 0.06 & 0.07 & 0.04 & 4.1 \\
\hline 24-in. & 5.10 & 0.08 & 0.08 & 0.05 & 5.8 \\
\hline 30-in. & 7.50 & 0.09 & 0.09 & 0.06 & \\
\hline
\end{tabular}

These prices, however, are sometimes far from the actual cost.

Let us consider the proposed gas-lines to New Orleans and St. Louis, the length of each being about 400 miles. The former, a great undertaking, will necessitate the laying of 18in. pipe for 400 miles through swamps and bayous, and the crossing of the Atchafalaya and the Mississippi rivers. Assuming $\$ 4.15$ as an average total cost per foot, the cost will amount to $\$ 8,764,800$. Very few appreciate the enormous expenditures represented by these pipe-lines.

Another considerable cost to a company operating on a large scale are the large steel storage- and cooking-tanks. The Producers' Oil Co. has a 50,000-barrel tank in the Caddo field, which cost about $\$ 14,000$. The Caddo Gas \& Oil Co. owns a 35,000-barrel steel tank, which cost about $\$ 9,800$.

\section{Life of the Field.}

Under this head, Prof. G. D. Harris ${ }^{2}$ points out the important circumstance that the Caddo field is not one of extreme local concentration, and has nothing in common with the Beaumont or Jennings fields. In everything except its geologic age, it resembles the oil-fields of western Pennsylvania, West Virginia, Ohio, and Illinois. Its vastness speaks well for both quantity of oil and gas and the longevity of the field as a productive source of these materials.

I wish to express publicly my thanks to Prof. Heinrich Ries for criticism and suggestions; to Prof. G. D. Harris for suggestions and for the photographs used in this article, and to Donald Steel, of Cornell University, for helpful criticisms.

${ }^{2}$ Oil Investors' Journul, vol. vii., No. 11, p. 18 (Nov. 6, 1908). 